\title{
Komparasi Pengaruh Efikasi Diri, Kebiasaan Belajar dan Lingkungan Sekolah Terhadap Hasil Belajar Matematika Siswa SMK
} Hardimansyah ${ }^{1 *}$, Ganefri², Ali Amran ${ }^{3}$

\footnotetext{
1,2,3 Jurusan Pendidikan Teknologi Kejuruan, Universitas Negeri Padang, Padang, Indonesia
} *e-mail: hardiamansyah@gmail.com

\begin{abstract}
Abstrak
Hasil belajar siswa pada pelajaran matematika kelas XI masih banyak yang belum mencapai KKM karen dianggap paling sulit oleh siswa. Jenis penelitian adalah kuantitatif dengan pendekatan korelasional. Subjek penelitian ini adalah seluruh siswa kelas XI di SMKN 2 Gunung Talang sebanyak 34 siswa, SMKN 1 Gunung Talang sebanyak 25 siswa dan SMKN 1 Bukit Sundi sebanyak 48 siswa yang total subjek penelitian yang digunakan adalah 107 orang siswa. Instrumen pengumpulan data menggunakan kuisioner. Teknik analisis data diantaranya regresi sederhana dan regresi berganda. Hasil penelitian menunjukkan bahwa terdapat komparasi pengaruh yang signifikan efikasi diri terhadap hasil belajar matematika di SMKN Kabupaten Solok. Terdapat komparasi pengaruh yang signifikan kebiasaan belajar terhadap hasil belajar matematika di SMKN Kabupaten Solok. Terdapat komparasi pengaruh yang signifikan lingkungan sekolah terhadap hasil belajar matematika di SMKN Kabupaten Solok. Terdapat komparasi pengaruh yang signifikan efikasi diri, kebiasaan belajar dan lingkungan sekolah terhadap hasil belajar matematika pada beberapa SMK di kabupaten Solok. Dari kegita aspek tersebut yaitu efikasi diri, kebiasaan belajar dan lingkungan sekolah berpengaruh terhadap hasil belajar matematika pada beberapa SMK di kabupaten Solok.
\end{abstract}

Kata kunci: efikasi diri, kebiasaan belajar, lingkungan

\begin{abstract}
There are still many students' learning outcomes in class XI mathematics that have not reached the KKM because they are considered the most difficult by students. This type of research is quantitative with a correlational approach. The subjects of this study were all students of class XI at SMKN 2 Gunung Talang as many as 34 students, SMKN 1 Gunung Talang as many as 25 students, and SMKN 1 Bukit Sundi as many as 48 students whose total research subjects used were 107 students. The data collection instrument used a questionnaire. Data analysis techniques include simple regression and multiple regression. The results showed that there was a significant comparison of the effect of self-efficacy on mathematics learning outcomes at SMKN Solok Regency. There is a significant comparison of the effect on mathematics learning outcomes at SMKN Solok Regency. There is a significant comparison of the influence of the school environment on mathematics learning outcomes at SMKN Solok Regency. There is a significant comparison of the effect of self-efficacy, study habits, and school environment on mathematics learning outcomes in several vocational schools in the Solok district. From the aspect of these activities, namely self-efficacy, study habits, and school environment affect the learning outcomes of mathematics in several vocational schools in Solok district.
\end{abstract}

Keywords: self-efficacy, study habits, environment

\section{Pendahuluan}

Tolak ukur keberhasilan pendidikan salah atunya adalah dari hasil belajar. Hasil belajar yang berkualitas akan meningkatkan mutu pendidikan di sekolah. Mutu pendidikan sekolah mencakup tiga kemampuan yaitu kemampuan akademik, kemampuan sosial dan kemampuan moral Zamroni dalam (Kusumawati, 2017). Proses pendidikan dikategorikan 
bermutu jika memiliki prestasi akademik yang baik. Tingkat keberhasilan belajar siswa dalam kemampuan akademik dapat diketahui dari persentase jumlah siswa yang memiliki nilai di atas Kriteria Kentuntasan Minimal (KKM) yang telah ditetapkan oleh sekolah. Hasil belajar siswa meliputi tiga ranah yaitu: ranah kognitif, ranah afektif dan ranah Psikomotor (Sudjana, 1989). Hasil tersebut dapat diukur dan dinilai dengan tujuan mengetahui standar mutu yang telah dicapai oleh sekolah.

Matematika merupakan salah satu dari mata pelajaran yang memegang peranan penting bagi siswa. Matematika diberikan kepada seluruh siswa atau peserta didik dimulai dari jenjang sekolah dasar hingga ke tingkat perguruan tinggi guna melengkapi peserta didik dengan kemampuan berpikir secara logis, menganalisis, berfikir sistematis, kritis, kreatif dan juga kemampuan bekerjasama. Faktor-faktor yang menyebabkan timbulnya masalah-masalah dalam pembelajaran matematika antara lain masih banyak siswa beranggapan bahwa mata pelajaran matematika adalah pelajaran yang sukar dan biasanya belajar matematika memerlukan konsentrasi tinggi. Matematika adalah mata pelajaran yang paling tidak disukai oleh sebagian besar siswa (Abdurrahman, 2009; Intisari, 2017). Siswa menganggap matematika suatu pelajaran yang menankutkan, membosankan dan menjadi beban bagi siswa karena bersifat abstrak, penuh dengan angka dan rumus. Siswa juga memiliki minat yang kurang terhadap mata pelajaran matematika (sari, F.M., dan Harini, 2015). Selain itu, masih ada system belajar yang menyamaratakan kemampuan siswa. Saat siswa belum menguasai materi disarankan sudah ditambah dengan materi lain. Para siswa cenderung tidak menyukai matematika karena dianggap sulit terutama dalam menyelesaikan soal-soal yang diberikan oleh guru matematika. Faktor eksternal seperti variasi mengajar, media, sarana prasana dan lingkungan keluarga diduga menjadi penyebabnya (Anditiasari, 2020).

Dari berbagai bidang studi yang diajarkan di sekolah, matematika merupakan bidang studi yang dianggap paling sulit oleh siswa, baik yang tidak berkesulitan belajar dan lebih bagi siswa yang berkesulitan belajar (Abdurrahman, 2009). Matematika merupakan kunci untuk ilmu eksak lainnya, seperti fisika, kimia, biologi dan bahkan ilmu matematika sangat berhubungan dengan kehidupan sehari-hari. Tak terlepas dari hal tersebut, matematika juga berhubungan dengan mata pelajaran kejuruan terutama analisis rangkayan listrik pada bidang studi di jurusan elektromanika. Belajar ilmu analisis rangkayan listrik harus terlebih dahulu mengetahui prinsip dan konsep dasar mata pelajaran matematika, yang bilamana hal tersebut bisa dioptimalkan dalam kegiatan pembelajaran dapat memberikan suatu keberhasilan dalam menangkap atau memahami mata pelajaran kejuruan yang merupakan mata pelajaran baru yang dijumpai oleh para siswa.

Salah satu cara agar peserta didik dapat belajar dengan baik dan menghasilkan prestasi belajar yang baik salah satunya dengan menumbuhkan keyakinan dan persepsi positif pada diri peserta didik. Karena keyakinan dalam diri peserta didik mempengaruhi perilaku yang dilakukan peserta didik tersebut dalam pembelajaran di kelas. Tinggi rendahnya keyakinan dalam diri seseorang disebut juga efikasi diri. Bandura dalam Feist (2016) menyatakan bahwa keyakinan manusia sebagai efikasi diri mempengaruhi bentuk tindakan yang akan mereka pilih untuk dilakukan sebanyak usaha yang akan mereka berikan kedalam aktivitas ini, selama apa mereka akan bertahan dalam menghadapi rintangan dan kegagalan serta ketangguhan mereka mengikuti adanya kemunduran. Selain itu, persepsi siswa berpengaruh terhadap hasil belajar siswa (Fitroh \& Sari, 2018).

Peserta didik mungkin saja meyakini bahwa sebuah hasil yang positif akan diperoleh dari tindakan-tindakan tetapi mereka kurang memiliki kompetensi untuk melakukan perbaikan dari tindakan-tindakan tersebut. Efikasi diri dapat mempengaruhi pilihan aktivitas. Para peserta didik dengan efikasi diri yang rendah cenderung berperilaku malas mengerjakan tugas, seenaknya sendiri, kurang terlibat dalam proses belajar di dalam kelas, berdampak pada nilai akademis yang belum tuntas, begitupun sebaliknya apabila mereka memiliki efikasi diri yang tinggi maka mereka akan bersemangat dalam menyelesaikan tugas dan berdampak pada nilai akademis yang tinggi (Rahmania, 2018). Efikasi diri dapat diperoleh, dipelajari dan dikembangkan dari empat sumber informasi 
yaitu pengelaman keberhasilan dan pencapaian prestasi; pengalaman orang lain; persuasi verbal; dan keadaan psikologi dan psikologi (Lely. Suryani, 2020). Hasil penelitian (Kholidin, 2020) menunjukkan bahwa ada kontribusi dari efikasi diri akademik pada nilai akhir mata kuliah statistik inferensial. Efikasi diri memiliki pengaruh positif dan signifikan terhadap hasil bealjar siswa (Lely. Suryani, 2020; Uran, 2019).

Belajar merupakan kewajiban bagi seorang siswa untuk mewujudkan tujuan pendidikan nasional. Apabila semua siswa di Indonesia mempunyai Kebiasaan Belajar yang baik maka dengan mudah tujuan pendidikan nasional akan tercapai (Retnowati, 2017). Kunci utama dari keberhasilan belajar siswa adalah kebiasaan belajar baik (Rosyida, 2016). Kebiasaan belajar baik akan membuat siswa memperoleh prestasi belajar tinggi. Hal ini disebabkan karena kebiasaan belajar yang baik akan mampu menciptakan suasana belajar yang benar-benar mendukung untuk belajar. Kebiasaan belajar memang lebih mendominasi pada tingkah laku atau tindakan siswa setiap kali melakukan proses pembelajaran secara konsisten, dengan kata lain apabila siswa memiliki kebiasaan belajar dari dalam dirinya sudah baik, maka secara langsung akan memberikan dampak kepada siswa dalam menguasai materi pelajaran demi mencapai keberhasilan studinya di sekolah (Andrie, 2019). Kebiasaan belajar merupakan cara-cara yang harus ditempuh oleh siswa dalam melakukan kegiatan belajar dan dilakukan secara teratur dan berkesinambungan (Nurmalia, 2016). Kebiasaan belajar dapat diartikan cara atau teknik yang menetap pada diri siswa pada waktu menerima pelajaran, membaca buku, mengerjakan tugas dan pengaturan waktu untauk menyelesaikan kegiatan (Djaali, 2017). Hasil-hasil penelitian menunjukkan bahwa terdapat hubungan positif dan signifikan antara kebiasan belajar dengan hasil belajar (Andrie, 2019; Retnowati, 2017; Rusmiyati, 2017). Hasil penelitian lain juga menunjukkan bahwa terdapat penagruh yang positif dan signifikan kebiasaan belajar terhadap hasil belajar (Sripatmi, 2019). Hasil-hasil penelitian tersebut menunjukkan bawah kebiasan belajar memiliki korelasi yang kuat dan positif terhadap hasil belajar.

Selain kebiasaan belajar, juga perlu di dukung oleh lingkungan siswa. Lingkungan sekolah merupakan lingkungan kedua bagi siswa setelah lingkungan keluarga. Lingkungan sekolah membantu siswa agar mampu mengembangakan potensinya baik yang menyangkut aspek moral, spiritual, intelektual, emosional maupun socal (Johnson, 2018). Lingkungan sekolah yang kondusif sangat mendukung bagi kenyamanan dan kelangsungan prose pembelajaran yang dialami oleh siswa di kelas. Lingkungan sekolah non fisik yaitu interaksi anatra guru dengan siswa dan interaksi siswa dengan siswa. Sedangkan lingkungan sekolah secara fisik yaitu sarana dan prasarana, keadaan gedung, ruang keals dan kelengkapan sekolah. Lingkungan sekolah dapat mempengaruhi kegiatan belajar siswa.

Faktor sekolah yang punya pengaruh pada prestasi belajar seorang siswa dapat dijabarkan meliputi kurikulum, standar pelajaran, metode mengajar, materi pelajaran, metode belajar, waktu di sekolah, tugas rumah, keadaan gedung, disiplin siswa, serta juga dilihat dari ikatan antara guru dengan peserta didik, maupun ikatan antar peserta didik (Slameto, 2015). Hasil penelitian menunjukkan bahwa bahwa lingkungan sekolah berhubungan positif dan signifikan dengan hasil belajar (Prianti, 2018; Retnowati, 2017). Dengan demikian tujuan penelitian ini adalah untuk mengetahui komparasi pengaruh efikasi diri, kebiasaan belajar dan lingkungan sekolah terhadap hasil belajar matematika siswa SMK.

\section{Metode}

Penelitian ini dilakukan dengan menggunakan metode kuantitatif melalui pendekatan korelasional. Subjek yang digunakan dalam penelitian ini adalah seluruh siswa kelas XI di SMKN 2 Gunung Talang sebanyak 34 siswa, SMKN 1 Gunung Talang sebanyak 25 siswa dan SMKN 1 Bukit Sundi sebanyak 48 siswa yang total subjek penelitian yang digunakan adalah 107 orang siswa. Sumber data yang digunakan dalam penelitian ini yaitu data primer merupakan data yang secara langsung didapat dari hasil 
penyebaran angket kepada responden, yaitu siswa. Instrumen yang digunakan dalam penelitian yaitu angket dengan menggunakan skala likert. Teknik analisis data yang digunakan yaitu (1) deskripsi data yaitu skor rata-rata ideal. (2) pengujian persyaratan analisis yaitu uji normalitas, uji linearitas, dan uji multikolinearitas. (3) Hipotesis menggunakan korelasi sederhana dan korelasi berganda. Data dianalisis dengan teknik analisis korelasi sederhana dilakukan untuk menguji hipotesis pengaruh tiap-tiap variabel $X$ pada variabel $Y$. Analisis korelasi ganda untuk mengetahui korelasi antara dua variabel bebas $(X)$ atau lebih secara bersama-sama dengan variabel terikat $(Y)$. Analisis regresi sederhana untuk memprediksi pengaruh variabel $X$ terhadap $Y$ dan analisis regresi ganda untuk memprediksi pengaruh variabel bebas secara bersama-sama terhadap variabel terikat. Untuk mengetahui besar kontribusi yang diberikan variabel bebas terhadap variabel terikat ditentukan dengan rumus koefisien determinan. Untuk sumbangan efektif (\%) dilakukan menggunakan rumus SE $(\mathrm{Xi}) \%=$ Koe. Regresi $\mathrm{Xi} \times$ Koe. Korelasi $(\mathrm{Xi}) \mathrm{x}$ $100 \%$. Untuk sumbangan relatif (\%) dilakukan menggunakan rumus $S R(X i)=\frac{S E(X i) \%}{R^{2}}$

\section{Hasil dan Pembahasan}

Sebelum melakukan pengujian hipotesi, dapat dilakukan pendeskripsian data, uji asumsi klasik terlebih dahulu yang meliputi uji normalitas, uji lineraritas dan multikolinearitas. Data yang dipaparkan dalam penelitian ini adalah data hasil konsep diri, kebiasaan belajar, dan lingkungan sekolah sebagai variabel bebas $(X)$ dan hasil belajar matematika sebagai variabel terikat $(\mathrm{Y})$. Data efikasi diri siswa SMKN 2 Gunung Talang yang dijadilkan sampel dalam penelitian sebanyak 34 siswa. hasil penelitian skor jawaban terendah 46 dan tertinggi 65 , dengan mean (rata-rata) 55,09, median 55 , mode 57 , dan standar deviasi 5,479. Dari data terlihat bahwasanya capaian variabel efikasi diri berkategori baik. Hal ini berdasarkan kategori tersebut memiliki nilai yang sangat dominan. Jadi berdasar hasil temuan dapat disimpulkan efikasi diri berada pada ketegori baik untuk SMKN 2 Gunung Talang.Kebiasaan belajar siswa SMKN 2 Gunung Talang diperoleh skor skor jawaban terendah 41 dan tertinggi 69, dengan mean (rata-rata) 56, median (skor tengah) 56, mode (skor yang banyak muncul) 48, dan standar deviasi (simpangan baku) 7,398. Dari data tersebut dapat menunjukkan bahwa capaian variabel kebiasaan belajar berkategori baik. Hal ini berdasarkan kategori tersebut memiliki nilai yang sangat dominan. Jadi berdasar hasil temuan dapat disimpulkan kebiasaan belajar berada pada ketegori baik untuk SMKN 2 Gunung Talang.

Distribusi lingkungan sekolah di SMKN 2 Gunung Talang skor jawaban terendah 77 dan tertinggi 112, dengan mean (rata-rata) 93,71, median (skor tengah) 94,50, mode (skor yang banyak muncul) 100, dan standar deviasi (simpangan baku) 9,077. Dari data diatas dapat menunjukkan bahwa capaian variabel lingkungan sekolah berkategori baik. Hal ini berdasarkan kategori tersebut memiliki nilai yang sangat dominan. Jadi berdasar hasil temuan dapat disimpulkan lingkungan sekolah berada pada ketegori baik untuk SMKN 2 Gunung Talang. Distribusi frekuensi hasil belajar SMKN 2 Gubung Talang skor jawaban terendah 55 dan tertinggi 88, dengan mean (rata-rata) 72,66, median (skor tengah) 71,50, mode (skor yang banyak muncul) 72, dan standar deviasi (simpangan baku) 9,42. Dari data tersebut dapat menunjukkan bahwa capaian variabel hasil belajar berkategori baik. Hal ini berdasarkan kategori tersebut memiliki nilai yang sangat dominan. Jadi berdasar hasil temuan dapat disimpulkan hasil belajar berada pada ketegori baik untuk SMKN 2 Gunung Talang. Berdasarkan hasil Penelitian di SMKN 1 Gunung Talang diperoleh skor efikasi diri terendah 46 dan tertinggi 72 , dengan mean (rata-rata) 57,04, median (skor tengah) 57, mode (skor yang banyak muncul) 52, dan standar deviasi (simpangan baku) 7,607. Dari data tersebut menunjukkan bahwa capaian variabel efikasi diri berkategori baik dan sangat baik. Hal ini berdasarkan kategori tersebut memiliki nilai yang sangat dominan. Jadi berdasar hasil temuan dapat disimpulkan efikasi diri berada pada ketegori baik dan sangat baik untuk SMKN 1 Gunung Talang.

Distribusi frekuensi kebiasasan belajar diperoleh skor jawaban terendah 41 dan tertinggi 67 , dengan nilai rata-rata atau mean 55,28, median atau skor tengah 54 , skor 
terbanyak yang muncul atau mode 51, dan simpangan baku atau standar deviasi 7,481. Data tersebut menunjukkan dimana, capaian variabel kebiasaan belajar berkategori baik. Hal ini berdasarkan kategori tersebut memiliki nilai yang sangat dominan. Jadi berdasar hasil temuan dapat disimpulkan kebiasaan belajar berada pada ketegori baik untuk SMKN 1 Gunung Talang. Distribusi lingkungan sekolah di SMKN 1 Gunung Talang diperoleh skor jawaban terendah 79 dan tertinggi 120, dengan mean (rata-rata) 94, median (skor tengah) 90, mode (skor yang banyak muncul) 86, dan standar deviasi (simpangan baku) 11,68. Dari data diatas dapat menunjukkan bahwa capaian variabel lingkungan sekolah berkategori sedang. Hal ini berdasarkan kategori tersebut memiliki nilai yang sangat dominan. Jadi berdasar hasil temuan dapat disimpulkan lingkungan sekolah berada pada ketegori sedang untuk SMKN 1 Gunung Talang.

Ditribusi hasil belajar SMKN 1 Gunung Talang diperoleh skor jawaban terendah 55 dan tertinggi 93,50, dengan rata-rata (mean) sebesar 73,48, skor tengah (median) 71,50, skor yang banyak muncul (mode) 71,50, dan simpangan baku (standar deviasi) 10,031. Berdasarkan hasil data diatas menampilkan bahwa capaian variabel hasil belajar berkategori baik. Hal ini berdasarkan kategori tersebut memiliki nilai yang sangat dominan. Jadi berdasar hasil temuan dapat disimpulkan hasil belajar berada pada ketegori baik untuk SMKN 1 Gunung Talang. Hasil Penelitian di SMKN 1 Bukit Sundi diperoleh skor efikasi diri jawaban terendah 45 dan tertinggi 72, dengan rata-rata (mean) sebesar 57,13, skor tengah (median) 56,50, skor yang banyak muncul (mode) 55, dan simpangan baku (standar deviasi) 6,769. Dari data tersebut menunjukkan bahwa capaian variabel efikasi diri berkategori baik. Hal ini berdasarkan kategori tersebut memiliki nilai yang sangat dominan. Jadi berdasar hasil temuan dapat disimpulkan efikasi diri berada pada ketegori baik untuk SMKN 1 Bukit Sundi.

Hasil distribusi kebiasaan belajar di SMKN 1 Bukit Sundi skor jawaban terendah 36 dan tertinggi 69, dengan rata-rata (mean) sebesar 55,63, skor tengah (median) 55, skor yang banyak muncul (mode) 47, dan simpangan baku (standar deviasi) 8,54. Dari data tersebut menunjukkan bahwa capaian variabel kebiasaan belajar berkategori baik. Hal ini berdasarkan kategori tersebut memiliki nilai yang sangat dominan. Jadi berdasar hasil temuan dapat disimpulkan kebiasaan belajar berada pada ketegori baik untuk SMKN 1 Bukit Sundi. Distribusi lingkungan sekolah di SMKN 1 Bukit Sundi diperoleh jawaban terendah 85 dan tertinggi 119, dengan rata-rata (mean) sebesar 96,23, skor tengah (median) 95, skor yang banyak muncul (mode) 90, dan simpangan baku (standar deviasi) 7,62. Dari data tersebut menunjukkan capaian variabel lingkungan sekolah berkategori baik. Hal ini berdasarkan kategori tersebut memiliki nilai yang sangat dominan. Jadi berdasar hasil temuan dapat disimpulkan lingkungan sekolah berada pada ketegori baik untuk SMKN 1 Bukit Sundi.

Ditribusi hasil belajar di SMKN 1 Bukit Sundi diperoleh skor jawaban terendah 44 dan tertinggi 93,50, dengan rata-rata (mean) sebesar 79,2917, skor tengah (median) 79,75, skor yang banyak muncul (mode) 88 dan simpangan baku (standar deviasi) 12,52. $\mathrm{t}$ jelas capaian variabel hasil belajar berkategori sangat baik. Hal ini berdasarkan kategori tersebut memiliki nilai yang sangat dominan. Jadi berdasar hasil temuan dapat disimpulkan hasil belajar berada pada ketegori sangat baik untuk SMKN 1 Bukit Sundi.Sebelum melakukan analisis uji hipotesis, terlebih dahulu dilakukan uji asumsi diantara, uji normalitas, uji linearitasuji multikolinearitas. Untuk pengujian normalitas data digunakan untuk mengetahui apakah data berdistribusi secara normal atau tidak. Uji normalitas tersebut dilihat berdasarkan data Kolmogorov-Smirnov. Dimana jika nilai sig. uji Kolmogorov-Smirnov > 0,05 berarti distribusi data dinyatakan normal dan begitu pula sebaliknya. Tabel 1 menunjukkan bahwa nilai signifikansi Kolmogorov-Smirnov variabel efikasi firi, kebiasaan belajar dan lingkungan sekolah diperoleh signifikansi lebih besar 0,05 . Sehingga semua variabel berdistribusi normal. 
Tabel 1. Hasil Uji Normalitas denganTest Kolmogrov Smirnov

\begin{tabular}{llll}
\hline \multirow{2}{*}{ Variabel } & \multicolumn{3}{l}{ Sekolah /Jumlah siswa } \\
\cline { 2 - 4 } & $\begin{array}{l}\text { SMKN 2 } \\
\text { Gunung Talang }\end{array}$ & $\begin{array}{l}\text { SMKN 1 } \\
\text { Gunung Talang } \\
\text { (34) }\end{array}$ & $\begin{array}{l}\text { SMKN 1 } \\
\text { Bukit Sundi } \\
\mathbf{( 4 8 )}\end{array}$ \\
\hline Efikasi diri $\left(\mathrm{X}_{1}\right)$ & 0,914 & 0,659 & 0,696 \\
Kebiasaan belajar $\left(\mathrm{X}_{2}\right)$ & 0,737 & 0,876 & 0,750 \\
Lingkungan sekolah $\left(\mathrm{X}_{3}\right)$ & 0,735 & 0,315 & 0,329 \\
Hasil belajar $(\mathrm{Y})$ & 0,146 & 0,185 & 0,054 \\
\hline
\end{tabular}

Uji linieritas dipergunakan untuk melihat masing-masing variabel yang dipergunakan berupa variabel efikasi diri, kebiasaan belajar dan lingkungan sekolah mempunyai kecenderungan membangun distribusi linier padavariabel hasil belaja

Tabel 2. Hasil Uji Linearitas variabel efikasi diri $\left(X_{1}\right)$, kebiasaan belajar $\left(X_{2}\right)$, lingkungan sekolah $\left(\mathrm{X}_{3}\right)$ terhadap variabel hasil belajar $(\mathrm{Y})$ Masing-Masing Sekolah

\begin{tabular}{|c|c|c|c|}
\hline \multirow[b]{2}{*}{ Variabel } & \multicolumn{3}{|c|}{ Sekolah } \\
\hline & $\begin{array}{c}\text { SMKN } 2 \\
\text { Gunung Talang }\end{array}$ & $\begin{array}{l}\text { SMKN } 1 \text { Gunung } \\
\text { Talang }\end{array}$ & $\begin{array}{c}\text { SMKN 1 } \\
\text { Bukit Sundi }\end{array}$ \\
\hline $\begin{array}{l}\text { Efikasi diri terhadap hasil } \\
\text { belajar }\end{array}$ & 0,432 & 0,178 & 0,547 \\
\hline $\begin{array}{l}\text { Kebiasaan belajar terhadap } \\
\text { hasil belajar }\end{array}$ & 0,889 & 0,055 & 0,509 \\
\hline $\begin{array}{l}\text { Lingkungan sekolah } \\
\text { terhadap hasil belajar }\end{array}$ & 0,496 & 0,996 & 0,708 \\
\hline
\end{tabular}

Berdasarkan tabel 2 dapat diketahui nilai signifikansi deviation from linearity $>0.05$ untuk variabel berupa variabel efikasi diri $\left(X_{1}\right)$ terhadap hasil belajar $(Y)$, variabel kebiasaan belajar $\left(\mathrm{X}_{2}\right)$ terhadap hasil belajar $(\mathrm{Y})$ dan variabel lingkungan sekolah $\left(\mathrm{X}_{3}\right)$ terhadap hasil belajar (Y) masing-masing sekolah yaitu SMKN 2 Gunung Talang, SMKN 1 Gunung Talang dan SMKN 1 Bukit Sundi. Ini menjelaskan antara variabel efikasi diri, kebiasaan belajar dan lingkungan sekolah terhadap hasil belajar berpola linear untuk masing-masing sekolah. Berdasar olahan data statistik yang dihasilkan didapatkan hasil nilai uji multikolinearitas data untuk masing-masing sekolah pada Tabel 3.

Tabel 3. Hasil Uji Multikolinearitas variabel efikasi diri $\left(X_{1}\right)$, kebiasaan belajar $\left(X_{2}\right)$, lingkungan sekolah $\left(\mathrm{X}_{3}\right)$ Masing-Masing Sekolah

\begin{tabular}{|c|c|c|c|c|c|c|}
\hline \multirow[t]{3}{*}{ Variabel } & \multicolumn{6}{|c|}{ Sekolah } \\
\hline & \multicolumn{2}{|c|}{$\begin{array}{c}\text { SMKN } 2 \text { Gunung } \\
\text { Talang }\end{array}$} & \multicolumn{2}{|c|}{$\begin{array}{c}\text { SMKN } 1 \text { Gunung } \\
\text { Talang }\end{array}$} & \multicolumn{2}{|c|}{$\begin{array}{l}\text { SMKN } 1 \text { Bukit } \\
\text { Sundi }\end{array}$} \\
\hline & Tolerance & VIF & Tolerance & VIF & Tolerance & VIF \\
\hline \multirow{3}{*}{$\begin{array}{l}\text { Efikasi diri } \\
\text { Kebiasaan } \\
\text { belajar } \\
\text { Lingkungan } \\
\text { sekolah }\end{array}$} & 0,558 & 1,793 & 0,775 & 1,290 & 0,943 & 1,061 \\
\hline & 0,614 & 1,629 & 0,897 & 1,115 & 0,810 & 1,234 \\
\hline & 0,649 & 1,541 & 0,802 & 1,246 & 0,774 & 1,292 \\
\hline
\end{tabular}

Berdasarkan tabel di atas diperoleh nilai tolerance masing-masing variabel variabel besar dari 0,1 dan nilai VIF $<10$, maka dapat disimpulkan bahwa data ketiga variabel bebas pada model regresi untuk SMKN 2 Gunung Talang, SMKN 1 Gunung Talang dan SMKN 1 Bukit Sundi tidak terdapat masalah multikolinearitas antara variabel bebas. Pengujian hipotesis dapat dilakukan apabila telah memenuhi ketiga uji asumsi telah dilakukan. Uji hipotesis dilakukan dengan menggunakan teknik analisis korelasi sederhana untuk menguji hipotesis 1 dan 2 dan analisis regresi korelasi berganda untuk 
menguji hipotesis 3 . Adapun hipotesis yang diuji adalah hipotesis nol $\left(\mathrm{H}_{0}\right)$. Koefesien korelasi ditunjukkan berdasarkan data koefesien korelasi pearson (r), koefisien korelasi ini dpergunakan untuk melihat hubungan variabel efikasi diri, kebiasaan atau pola belajar dan lingkungan sekolah terhadap hasil belajar pada masing-masing sekolah seperti yang terlihat pada table 4 .

Tabel 4. Korelasi efikasi diri $\left(X_{1}\right)$, kebiasaan belajar $\left(X_{2}\right)$, dan lingkungan sekolah $\left(X_{3}\right)$ Terhadap Hasil Belajar (Y) Masing-Masing Sekolah

\begin{tabular}{llcc}
\hline \multicolumn{1}{c}{ Variabel } & \multicolumn{1}{c}{ Sekolah / Jumlah Siswa } \\
\cline { 2 - 4 } & $\begin{array}{c}\text { SMKN 2 } \\
\text { Gung Talang } \\
\mathbf{( 3 4 )}\end{array}$ & $\begin{array}{c}\text { SMKN 1 Gunung } \\
\text { Talang } \\
\mathbf{( 2 5 )}\end{array}$ & $\begin{array}{c}\text { SMKN 1 } \\
\text { Bukit Sundi } \\
\mathbf{( 4 8 )}\end{array}$ \\
\hline $\begin{array}{l}\text { Efikasi diri terhadap hasil } \\
\text { belajar }\end{array}$ & 0,681 & 0,606 & 0,327 \\
$\begin{array}{l}\text { Kebiasaan belajar terhadap } \\
\text { hasil belajar }\end{array}$ & 0,661 & 0,484 & 0,427 \\
$\begin{array}{l}\text { Lingkungan sekolah } \\
\text { terhadap hasil belajar }\end{array}$ & 0,674 & 0,738 & 0,502 \\
\hline $\begin{array}{l}\boldsymbol{R} \text { product moment }(\boldsymbol{r} \\
\text { tabel) }\end{array}$ & $\mathbf{0 , 3 2 9}$ & $\mathbf{0 , 3 8 1}$ & $\mathbf{0 , 2 7 9}$ \\
\hline
\end{tabular}

Dari ketiga sekolah tersebut dapat disimpulkan bahwa korelasi tertinggi untuk efikasi diri terhadap hasil belajar adalah terdapat pada SMKN 2 Gunung Talang sebesar 0,681 . Hal ini berarti efikasi diri siswa SMKN 2 Gunung Talang lebih baik dibandingkan dengan SMKN 1 Gunung Talang dan SMKN 1 Bukit Sundi. Jika dilihat korelasi tertinggi untuk kebiasaan belajar terhadap hasil belajar adalah juga terdapat pada SMKN 2 Gunung Talang sebesar 0,661. Hal ini berarti kebiasaan belajar siswa di SMKN 2 Gunung Talang lebih tinggi dibandingkan SMKN 1 Gunung Talang dan SMKN 1 Bukit Sundi. Hal ini disebabkan SMKN 2 Gunung Talang ini berada di kawasan lingkungan pemerintahan, dimana siswa disini memiliki daya saing yang tinggi untuk memperoleh hasil belajar yang tinggi.

Sementara untuk korelasi tertinggi lingkungan sekolah terhadap hasil belajar terdapat pada SMKN 1 Gunung Talang sebesar 0,738. Hal ini berarti lingkungan sekolah di SMKN 1 Gunung Talang lebih baik dibandingkan dengan SMKN 2 Gunung Talang dan SMKN 1 Bukit Sundi. Hal ini disebabkan karena SMKN 1 Gunung Talang ini berdiri tahun 2002 lebih lama dibandingkan dengan SMKN 2 Gunung Talang tahun 2007 dan SMKN 1 Bukit Sundi tahun 2010. Lamanya berdiri sekolah ini tentu mempengaruhi fasilitas yang dimiliki oleh sekolah. Selanjutnya untuk korelasi terendah untuk efikasi diri terhadap hasil belajar adalah terdapat pada SMKN 1 Bukit Sundi sebesar 0,327, begitu juga dengan korelasi terendah untuk kebiasaan belajar terhadap hasil belajar adalah juga terdapat pada SMKN 1 Bukit Sundi sebesar 0,427, kemudian untuk korelasi terendah lingkungan sekolah terhadap hasil belajar juga terdapat pada SMKN 1 Bukit Sundi sebesar 0,502. Berdasarkan hasil pengujian hipotesis pertama penelitian menunjukkan bahwa terdapat komparasi pengaruh efikasi diri terhadap hasil belajar matematika di SMKN Kabupaten Solok. Hal ini berarti semakin tinggi efikasi diri siswa maka hasil belajar siswa juga meningkat. Jika dilihat dari masing-masing sekolah, dimana tingkat efikasi diri siswa yang paling tinggi yaitu di SMKN 2 Gunung Talang, kemudian SMKN 1 Gunung Talang dan yang terendah yaitu SMKN 1 Bukit Sundi.

Hasil pengujian hipotesis kedua menunjukkan bahwa terdapat komparasi pengaruh kebiasaan belajar terhadap hasil belajar matematika di SMKN Kabupaten Solok. Hal ini berarti semakin baik kebiasaan belajar siswa maka hasil belajar siswa juga meningkat. Jika dilihat dari masing-masing sekolah, dimana kebiasaan belajar siswa yang paling baik yaitu di SMKN 2 Gunung Talang, kemudian SMKN 1 Gunung Talang dan yang terendah yaitu SMKN 1 Bukit Sundi. Hasil pengujian hipotesis ketiga menunjukkan bahwa 
terdapat komparasi pengaruh lingkungan sekolah terhadap hasil belajar matematika di SMKN Kabupaten Solok. Hal ini berarti semakin baik lingkungan sekolah siswa maka hasil belajar siswa juga meningkat. Jika dilihat dari masing-masing sekolah, dimana lingkungan sekolah siswa yang paling baik yaitu di SMKN 1 Gunung Talang, kemudian SMKN 2 Gunung Talang dan yang terendah yaitu SMKN 1 Bukit Sundi.

Tabel 5. Hasil Uji Koefisien Korelasi Secara Bersama, Koefisien Determinasi Secara Bersama dan Analisis regresi linier berganda Pengaruh efikasi diri $\left(X_{1}\right)$, kebiasaan belajar $\left(\mathrm{X}_{2}\right)$, dan lingkungan sekolah $\left(\mathrm{X}_{3}\right)$ Terhadap Hasil Belajar $(\mathrm{Y})$ Masing-Masing Sekolah

\begin{tabular}{llllll}
\hline \multicolumn{1}{c}{ Sekolah } & \multicolumn{1}{c}{$\begin{array}{c}\text { Koefisien } \\
\text { Korelasi (R) }\end{array}$} & $\begin{array}{c}\text { Koefisien } \\
\text { Penentu } \\
(\mathbf{R} \text { square) }\end{array}$ & \multicolumn{2}{c}{$\begin{array}{c}\text { Hasil Regresi Linier } \\
\text { Berganda }\end{array}$} \\
\cline { 5 - 6 } & & & F hittung & Sig \\
\hline $\begin{array}{l}\text { SMKN 2 Gunung } \\
\text { Talang }\end{array}$ & 0,805 & 0,648 & 18,433 & 0,000 \\
SMKN 1 Gunung & & & & \\
Talang & 0,843 & 0,710 & 17,178 & 0,000 \\
SMKN 1 Bukit Sundi & 0,610 & 0,372 & 8,706 & 0,000 \\
\hline
\end{tabular}

Hasil pengujian hipotesis menunjukkan bahwa terdapat komparasi pengaruh efikasi diri, kebiasaan belajar dan lingkungan sekolah secara bersama-sama terhadap hasil belajar matematika di SMKN Kabupaten Solok. Hal ini berarti semakin tinggi efikasi diri, kebiasaan belajar dan lingkungan sekolah maka hasil belajar siswa juga meningkat. Jika dilihat dari masing-masing sekolah, dimana tingkat efikasi diri dan kebiasaan belajar siswa yang paling tinggi yaitu di SMKN 2 Gunung Talang, kemudian SMKN 1 Gunung Talang dan yang terendah yaitu SMKN 1 Gunung Talang. Sedangkan untuk lingkungan sekolah yang paling tinggi SMKN 2 Gunung Talang, kemudian SMKN 2 Gunung Talang dan terendah SMKN 1 Bukit Sundi. Perasaan positif yang tepat tentang efikasi diri dapat mempertinggi prestasi, meyakini kemampuan, mengembangkan motivasi internal, dan mumungkinkan siswa untuk meraih tujuan yang menantang Bandura dalam (Widyastuti, 2019). Efikasi diri merupakan sebuah kayakinan individu supaya dapat menagtasi permasalahan atau tugas dan melakukan tindakan yang dibutuhkan untuk mencapai tujuan atau prestasi yang diinginkan. Efikasi diri dapat mempengaruhi cara individu dalam memilih tindakan, beberapa banyak usaha yang dikerahkan, seberapa akan bertahan dalam menghadapi tantang dan kegagalan, sejaugmana kejernihan berpikir, serta seberapa tingi usaha yang mereka kerakan untuk mewujudkan keinginan guna mencapai prestasi tersebut (Ali et al., 2020) .

Siswa yang memiliki efikasi diri terhadap pembelajaran cenderung memiliki keteraturan yang lebih (menetapkan tujuan, penggunaan strategi pembelajaran aktif, mengevaluasi kemajuan tujuan) dan menciptakan lingkungan efektif untuk belajar (menghilangkan atau meminimalkan gangguan, menemukan mitra belajar efektif) (Wulandari, 2018). Efikasi diri akademik sangat penting bagi pelajar untuk mengontrol motivasi mencapai harapan-harapan akademik. Efikasi diri akademik jika disetai dengan tujuan-tujuan yang spesifik dan pemahaman mengenei akademik, maka akan menjadi penentu suksesnya perilaku akademik di masa yang akan datang (Lely. Suryani, 2020; Yuliyani, 2017). Hasil penelitan sejalan dengan penelitian (Syahrudin, 2019) yang mengemukan bahwa terdapat pengaruh efikasi diri dan dukungan sosial teman sebaya secara simultan terhadap prestasi belajar. Penelitian lain juga mengemukakan bahwa efikasi diri memiliki pengaruh positif dan signifikan terhadap hasil belajar (Kholidin, 2020; Lili Suryani et al., 2017). Hal tersebut sejalan dengan pendapat (Sudjana, 2010) menyatakan bahwa keberhasilan siswa dalam mengikuti pelajaran banyak bergantung kepada kebiasaan belajar yang teratur dan berkesinambungan. Kebiasaan belajar mandiri siswa yang baik akan memiliki tingkat hasil belajar yang tinggi (Slameto, 2015). Sebaliknya siswa yang memiliki kebiasaan belajar mandiri yang kurang menyebabkan 
rendahnya hasil belajar siswa itu sendiri. Berhasil mencapai hasil belajar yang tinggi sangat tergantung dari usaha siswa itu sendiri, siswa harus memiliki kemampuan belajar mandiri dengan cara membangun pengetahuan dalam pikiran, memanfaatkan kesempatan untuk menemukan atau merapkan sendiri gagasan-gasan dan menggunakan strategi belajar yang dimiliki.

Kebiasaan belajar baik daris segi waktu belajar, cara belajar, suasana belajar maupun keteraturan belaja merupakan factor penunjang keberhasilan belajar peserta didik (Rusmiyati, 2017). Dalam kehidupan sehari-hari ada kebiasaan baik dan ada pula kebiasaan buru yang dilakukan oleh siswa. Kebiasaan buruk biasanya disebabkan oleh ketidakmenegrtian siswa arti belajar bagi diri sendiri. Pemberian penguatan dalam keberhasilan belajar dapat mengurangi kebiasaan kurang baik dan membangkitkan harga diri siswa untuk itu kebiasaan belajar harus dibentuk mulai sejak dini agar factor ini dapat berlanjut sampai dewasa. Hasil penelitian ini sejalan dengan penelitian (Retnowati, 2017) menyatakan bahwa terdapat hubungan positf dan signifikan antara kebiasaan belaar dengan hasil belajar IPS. Kebiasaan belajar berpenagruh signifikan terhadap prestasi belajar (Andrie, 2019; Rusmiyati, 2017). Hasil penelitian lain juga menunjukkan hal yang sama bahwa kebiasaan belajar memiliki pengaruh positif terhadap hasil belajar (Eva, 2018; Menhard, 2018; Sripatmi, 2019).

Jika dilihat dari derajat pencapai responden dan ditribusi frekuensi lingkungan sekolah, dimana frekuensi paling baik di SMKN 1 Bukit Sundi berada pada rentang sangat baik dan baik. Hal ini dilihat dimana siswa belajar pada ruang kelas yang cukup besar, siswa meminjam buku cetak matematikan di perpustakaan sekolah, rungan-ruangan yang ada di sekolah memiliki ventilasi udara yang standar serta sekolah telah mulai menerapkan kurikulum yang meningkatkan keinginan belajar siswa. Sedangkan lingkungan sekolah yang memiliki derapat pencapaian yang paling rendah yaitu SMKN 2 Gurung Talang sesuai dengan jawaban responden. Hal ini disebabkan karena ventilasi udara kurang baik fungsinya sehingga ketika belajar jadi panas, sekolah belum menyediakan taman bermain yang nyaman, siswa kurang merasa senang mengunakan fasilitas-fasilitas yang disediakan oleh sekolah serta siswa takut mengajukan pertanyaan ketika tidak memahami materi. Lingkungan belajar itu mendukung dan berperan besar dalam keberhasilan prestasi belajar anak didik (Purwanto, 2014). Ini berarti bahwa lingkungan belajar yang baik dan kondusif diharapkan dapat membangkitkan motivasi siswa untuk mencapai hasil belajar yang lebih baik. Salah satu lingkungan belajar yaitu lingkungan sekolah. Kondisi lingkungan pembelajaran efektif adalah salah satu aspek penting keberhasilan dalam proses pembelajaran yang dilakukan oleh guru. Hasil belajar siswa dapat meningkat apabila didukung oleh tempat belajar yang nyaman, siswa mendapatkan perhatian dari guru saat proses pembelajaran serta oemberian apresiasipada awal kegiatan pembelajaran agar memprrmudah proses pembealajran sehingga dapat meningkatkan hasil belajar siswa.

Hasil Penelitian menunukkan bahwa terdapat hubungan positif dan sangat signifikan anatra lingkungan sekolah terhadap hasil belajar peserta didik (Anggraini, 2017; Sulfemi, 2018). Hasil penelitian lainnya juga menunjukkan bahwa lingkungan sekolah memiliki hubungan positif terhadap prestasi belajar. Lingkungan belajar yang kondusif akan mendukung tercapai tujuan pembelajaran (Prianti, 2018; Riyadi, 2019). Selain dipengaruhi oleh faktor lingkunga, bahwa hasil belajar juga dipengaruhi oleh faktor dari dalam diri siswa, seperti kesehatan, intelegensi, minat dan motivasi serta cara belajar siswa. Sedangkan faktor eksternal yang mempengaruhi yaitu keluarga, sekolah, masyarakat dan linkungan sekitar. Faktor intern seperti kebiasan belajar dan efikasi diri secara signifikan berpengaruh terhadi hasil belajar siswa (Rosyida, 2016). Self efficacy dan kebiasan belajar merupakan faktor psikologi yang juga berpengaruh dalam menentukan hasil belajar. Karena sefl efficacy berbeperan sebagai pendorong sedangkan kebiasaan belajar sebagai strategi agar memperoleh hasil belajar yang baik. Hal ini didukung oleh hasil penelitian lainnya yang menunjukkan bahwa kebiasaan belajar memiliki hubungan dengan hasil belajar (Eva, 2018; Retnowati, 2017). 


\section{Simpulan}

Berdasarkan hasil analisis data serta pembahasan maka dapat disimpulkan bahwa Terdapat komparasi pengaruh yang signifikan efikasi diri terhadap hasil belajar matematika di SMKN Kabupaten Solok. Hal ini berarti semakin tinggi efikasi diri siswa maka hasil belajar siswa juga meningkat. Jika dilihat dari masing-masing sekolah, dimana tingkat efikasi diri siswa yang paling tinggi yaitu di SMKN 2 Gunung Talang, kemudian SMKN 1 Gunung Talang dan yang terendah yaitu SMKN 1 Bukit Sundi. Terdapat komparasi pengaruh yang signifikan kebiasaan belajar terhadap hasil belajar matematika di SMKN Kabupaten Solok. Hal ini berarti semakin baik kebiasaan belajar siswa maka hasil belajar siswa juga meningkat. Terdapat komparasi pengaruh yang signifikan lingkungan sekolah terhadap hasil belajar matematika di SMKN Kabupaten Solok. Hal ini berarti semakin baik lingkungan sekolah siswa maka hasil belajar siswa juga meningkat. Terdapat komparasi pengaruh yang signifikan efikasi diri, kebiasaan belajar dan lingkungan sekolah terhadap hasil belajar matematika pada beberapa SMK di kabupaten Solok. Hal ini berarti semakin baik efikasi diri, kebiasaan belajar dan lingkungan sekolah, maka akan meningkatkan hasil belajar.

\section{Daftar Pustaka}

Abdurrahman, M. 2009. (2009). Pendidikan Bagi Anak Berkesulitan Belajar. PT Rineka Cipta.

Ali, D., Syarifudin, M., \& Bakhtiar, N. (2020). Penerapan Model Pembelajaran Berbasis Masalah Untuk Meningkatkan Hasil Belajar IPA Siswa Kelas V SD Negeri 028 Rimbo Panjang Kecamatan Tambang. Instructional Development Journal, 3(1), 1. https://doi.org/10.24014/idj.v3i1.8631.

Anditiasari, N. (2020). Analisis Kesulitan Belajar Abk (Tuna Rungu) Dalam Menyelesaikan Soal Cerita Matematika. Mathline: Jurnal Matematika Dan Pendidikan Matematika, 5(2), 183-194. https://doi.org/10.31943/mathline.v5i2.162.

Andrie, S. (2019). Pengaruh Kebiasaan Belajar Terhadap Prestasi Belajar. Ekuita: Jurnal Pendidikan Ekonomi, 7(2), 117-121.

Anggraini, Y. (2017). Pengaruh Lingkungan Belajar Dan Disiplin Belajar Terhadap Hasil Belajar Kompetensi Keahlian Elektronika Industri Di Sekolah Menengah Kejuruan. Jurnal Pendidikan: Teori Penelitian Dan Pengembangan, 2(12).

Djaali. (2017). Psikologi Pendidikan. PT Bumi Aksara.

Eva, L. M. (2018). Pengaruh Kebiasaan Belajar dan Kemampuan Numerik terhadap Prestasi Belajar Matematika. Journal of Mathematics Science and Education, 2(1), $1-11$.

Fitroh, M. I., \& Sari, A. F. (2018). Pengaruh Persepsi Matematika Siswa Terhadap Hasil Belajar Siswa Di Smkn 1 Surabaya Tahun Ajaran 2017 / 2018. Jurnal Elektronik Pembelajaran Matematika, 5(2), 148-156.

Intisari. (2017). Persepsi Siswa Terhadap Mata Pelajaran Matematika. Jurnal Pendidikan Pascasarjana Magister PAI, 1(1), 62-71.

Johnson. (2018). Pengaruh Lingkungan Belajar Dan Kreativitas Belajar Siswa Terhadap Prestasi Belajar Ekonomi Siswa Kelas XI IPS SMA Negeri 1 Tanjung Beringin Kabupaten Serdang Bedagai Tahun Pelajaran 2017/2018. Jurnal Ekoanomi Pendidikan, 8(6).

Kholidin, F. (2020). Kontribusi Kepercayaan Diri dan Efikasi Diri Akademik terhadap Nilai fmata Kuliah Statistik Inferensial. 2(2), 46-54.

Kusumawati, O. D. T. (2017). Pengaruh Pola Asuh, Lingkungan Masyarakat dan Kedisiplinan Belajar Terhadap Hasil Belajar Siswa SD Kecamatan Bandungan. Educational Magement, 6(2), 13-14.

Menhard. (2018). Pengaruh Kebiasaan Belajar dan Kompetensi Dosen terhadap Prestasi Belajar pada Mahasiswa STIE Mahaputra Riau. Jurnal Pendidikan: Teori, Penelitian Dan Pengembangan, 2(12).

Nurmalia. (2016). Pengaruh Kebiasaan Belajar Siswa Terhadap Hasil Belajar Siswa Di 
Madrasah Aliah Negeri (MAN) Kreueng Geukueh Kabupaten Aceh Utara. Jurnal Sains Ekonomi Dan Edukasi, 4(1).

Prianti, E. N. 2018. (2018). Perngaruh Persepsi Lingkungan Sekolah terhadap prestasi bealar PPKn Siswa SMA Negeri Pandeglangs Banteng. Jurnal Pendidikan Pancasila Dan Kewarganegaran, 1(1).

Purwanto, M. N. (2014). Psikologi Pendidikan. PT Remaja Rosdakarya.

Rahmania, Y. (2018). Pengaruh Efikasi Diri, Komunikasi Interpersonal Guru dan media Pembelajaran Terhadap Perilaku Belajar. Economic Education Analysis Journal, $7(3)$.

Retnowati, F. (2017). hubungan kebiasaan belajar dan lingkungan sekolah terhadap hasil belajar IPS Kelas V. Hoyful Learning Journal., 6(3), 197-205.

Riyadi, M. I. (2019). Pengaruh Lingkungan Keluarga dan Lingkungan Sekolah Terhadap Prestasi Belajar Siswa Kelas V SD Negeri di Gugus Pangeran Diponegoro Genuk. Prosiding Konferensi IImiah Mahasiswa Unissula (KIMU) 2.

Rosyida, F. (2016). Pengaruh Kebiasaan Belaar dan Self efficacy terhadap Hasil Belaar Geografi di SMA. Jurnal Pendidikan Geografi: Kajian, Teori Dan Praktek Dalam Bidang Pendidikan Dan IImu Geografi, 21(1).

Rusmiyati, F. (2017). Pengaruh Kemandirian Dan Kebiasaan Belajaar Terhadap Prestasi Belajar Metematika Siswa Kelas X SMA Negeri 1 Rongkop. UNION: Jurnal Pendidikan Matematika, 5(1).

sari, F.M., dan Harini, E. (2015). Hubungan Persepsi Siswa terhadap Pelajaran Matematika, Minat Belajar, dan Kemandirian belajar dengan Hasil Belajar Matematika. Jurnal Pendidikan Matematika UNION, 3(1), 61-68.

Slameto. (2015). Belajar dan Faktor-Faktor yang Mempengaruhi. PT Rineka Cipta.

Sripatmi. (2019). Pengaruh Motivasi dan Kebiasaan Belajar Terhadap Hasil Belajar Matematika Siswa Kelas XI SMAN 1 Jonggat. Mandalika Mathematics and Education Journal, 1(1).

Sudjana, N. (1989). Penilaian Hasil Proses Belajar Mengajar. Remaja Rosdakarya.

Sudjana, N. (2010). Proses dan Hasil Belajar. Bumi Aksara.

Sulfemi, W. B. (2018). Penagruh Disiplin Ibadah Sholat, Lingkungan Sekolah dan Intelegensi terhadap Hasil Belajar Peserta Didik Mata Pelajaran Pendidikan Agama Islam. Jurnaal Penelitian Pendidikan Agaman Dan Keagamaan, 16(2), $166-178$.

Suryani, Lely. (2020). Pengaruh Efikasi Diri Dan Motivasi Belajar Terhadap Hasil Belajar Berbasis E-Learning pada Mahasiswa Program Studi pendidikan Matematika Universitar Flores. Jurnal Kependidikan: Jurnal Hasil Penelitian Dan Kajian Kepustakaan Di Bidang Pendidikan, Pengajaran Dan Pembelajaran, 6(2), 275283.

Suryani, Lili, Sahono, B., \& Somantri, M. (2017). Korelasi Kepemimpinan Kepala Sekolah dan Disiplin Antara Guru Terhadap Kinerja Guru Di SMPN Simpang Kosgoro Kab. Musi Rawas. Jurnal Manajer Pendidikan, 11(3).

Syahrudin. (2019). Pengaruh Efikasi diri dan Dukungan Sosial Teman Sebaya terhadap Prestasi Belajar.

Uran, A. L. (2019). Pengaruh Efikasi Diri Dan Dukungan Sosial Guru Terhadap Prestasi Belajar Matematika Siswa. Asimtot: Jurnal Pendidikan Matematika, 1(1), 69-76.

Widyastuti. (2019). Minat Siswa Terhadap Matematika dan Hubungannya dengan metode pembelajaran dan efikasi diri. Jurnal Pendidikan Matematika, 13(1), 83-100.

Wulandari, N. (2018). Pengaruh Kecerdasan Interpersonal, Kemampuan Berpikir Kritis, Dan Efikasi Diri Terhadap Hasil Belajar Matematika Dan Sikap Terhadap Matematika Siswa Kelas VIII Di Sekolah Menengah Pertama Di Kota Makassar. Prosiding Seminar Nasional VARIANSI. http://ojs.unm.ac.id/index.php

Yuliyani, R. (2017). Peran Efikasi Diri (Self Efficacy) Dan Kemampuan Berpikir Positif Terhadap Kemampuan Pemecahan Masalah Matematika. Jurnal Formatif, 7(2), 130-143. 